\title{
Mother (Indung) in Sundanese Myth on Visual Art
}

\author{
Rini Maulina $^{1^{*}} \quad$ Setiawan Sabana $^{1} \quad$ Nuning Yanti Damayanti ${ }^{1} \quad$ Teddi Muhtadin $^{2}$ \\ 1.Faculty of Arts and Design, Institut Teknologi Bandung \\ Ganesha 10, Bandung 40132, Indonesia \\ 2. Faculty of Humanities, Universitas Padjadjaran \\ Bandung Sumedang KM 21, Jatinangor, Sumedang, Indonesia
}

\begin{abstract}
Throughout the history of human civilization, the word Mother is found in all languages in the world. Sundanese as one of the ethnic groups in Indonesia who is speaking Sundanese. Mother in Sundanese is indung. In Sundanese culture, indung is not only has the meaning of biological mother, but indung has more meaning. Based on its understanding, the indung have feminine characteristics, such as gentleness, affection, protecting and caring. Referring to the understanding of the indung, the characteristic of the indung in Sundanese culture, is found in Sundanese mythological figures such as Sunan Ambu and Nyi Sri Pohaci (Dewi Sri). The research was conducted using Art based Research methods. The research was conducted through literature data collection aimed to get an overview of the indung figures in Sundanese mythology sourced from carita pantun and ancient manuscripts which then interpreted the meaning of the indung in visual artwork. The result of the study is the characteristics of the indung contained in the mythological figure such as Sunan Ambu ( in this case as Ambu Langit, Ambu tengah and Ambu Bumi) as well as Nyi Sri Pohaci who has the spirit of the indung that is guarding, protecting humans, and providing life for humans and other earth creatures. These characteristics are depicted in the form of two-dimensional display works with traditional visual styles, and the use of video technology with stop motion techniques.
\end{abstract}

Keywords: Goddess, Indung, Mythology, Sundanese, Visual Art.

DOI: $10.7176 / \mathrm{ADS} / 92-02$

Publication date: April $30^{\text {th }} 2021$

\section{Introduction}

Every language in the world has a word mother. Mother's understanding in all country has the same meaning, namely a woman who is pregnant, giving birth and caring for her children. In Indonesia there are more than 1000 ethnic groups living throughout the Indonesian archipelago. Java island is more inhabited by Javanese and Sundanese. Each ethnic group in Indonesia has its own special customs and cultures that become its identity (Na'im and Syaputra, 2010). Related to the statement, Indonesia has many different terms for the words of mother. One of the words of mother in Sundanese is indung. Indung has a meaning not only as a biological mother, but has a very wide meaning, based on literature, the meaning of indung is not limited as a mother, indung can mean nature, role, symbol, philosophy and so on. In this case Mustapa (1985) stated, "Sundanese people are stronger to consider indung (mothers) than bapa (fathers), it signifies the indung (mother) of all role models (something considered more, called indung and not called father)".

Based on Heryana's research (2006), indung is divided into two categories, namely biological and cultural indung. Biological indung is related to the nature of women and the role of women in domestic life. The indung as a mother has female traits such as meek, loving and caring. Cultural indung is the mention of indung that is intended not only to man but can be directed towards something, such as objects or other, taken from the indung is the nature of motherhood, the characteristic of the indung that is found in women. Mustafa (1985) gives an definition of the indung that is who educates children from younger, even if not human, should be called indung.

Indung as a concept has a scope contained in the philosophy and cosmology of Sundanese culture, the word indung in Sundanese culture can be found in Sundanese literature such as; carita pantun, paribasa, pupuh, kawih, and babasan. In carita pantun, indung character is found in mythological figures such as Sunan Ambu, Dayang Sumbi, and Nyi Sri Pohaci. The word indung contained in literary works is the result of Sundanese ability in developing their culture, as stated by Maulina (2019)," Sundanese people have the ability to create an idea that is realized through their abilities. Artifacts such as waditra (Sundanese traditional instruments) are the result of Sundanese people's ability to develop their cultural systems". The cultural system is, language, knowledge, social organization, technology, economy, religion and the arts (Koentjaraningrat, 2009), the entire cultural system embodies a variety of artificial forms and mediums, so that in his life people face a new reality that is the world of symbols (Prawira, 2017).

Characters of indung in mythological figures such as Sunan Ambu, Nyi Sri Pohaci are found in carita pantun and ancient manuscript. The depiction of Sunan Ambu as an indung character in mythology is found in pantun stories such as Lutung Kasarung (Heryana, 2012). Sunan Ambu is also found in the mythology of the Baduy people in the creation of man (Heryana, 2006). The mythological character of Nyi Sri Pohaci is found in 
Baduy mythology, and is found in the community of Rancakalong subdistrict of Sumedang district of West Java Province, namely Ngalaksa the traditional ceremony of worship of Nyi Sri Pohaci, found also in Cirebon Regency of West Java Province in the manuscript Satria Budug Basu. Sunan Ambu and Dewi Sri are symbols of the Goddess of caretaker and Goddess of help (Yanti, 2006).

In the belief of Kanekes people in Baduy Dalam, there is mythology about human creation, in the mythology there are Ambu Langit (mother of sky), Ambu Tengah (mother of middle) and Ambu Bumi (mother of earth). In the mythology of the creation of the earth in various tribes of the world there are also figures described as women, in the mythology of the Aborigines there is the figure of Yhi, who is described as the Goddess of the sun, giving life to nature (World Book, 1987). In Japanese Shinto beliefs, there are Izanami and Amaterasu characters as female Gods who create life on earth and the ancient Iranians reported that Yima, the god of fertility (Leeming, 2010). In The Hindu style of India there are figures Lalita and Sri Cakra (Kak, 2016).

There are similar stories and female characters in mythology throughout the world. Depictions of her are also varied, generally depictions of female figures in mythology are visualized in the form of women, made on three-dimensional sculptures, and two-dimensional paintings on reliefs, carpets, fabrics, ceramics and others such as the Maglemosians in the 10th century BC who lived in the Eridu region around the Caspian sea, they had the God of Enki made in the form of statues with female bodies. This could be due to what Stone (1976) stated, "Whatever the suggested order of cause and effect, one of the major factors which continually appears in the material concerned with the status and role of women in the ancient female religion in historic times is its close connection to female kinship, matrilineality, perhaps the very origins of its development. In examining the position of women, this mother or female structure, leading to matrilineal descent of name and property, should be carefully studied".

In Sundanese culture, it is difficult to find visual depictions of Goddess figures such as Sunan Ambu and Dewi Sri. This is related to the relics of Sundanese cultural artifacts in limited visual form. There has been no research that describes how Sunan Ambu and Nyi Sri Pohaci visually. This research was conducted to get an overview of the indung figures contained in Sundanese mythology such as carita pantun and ancient manuscripts. The results of the study are poured in the form of visual artwork. The purpose of research based on the creation of visual artworks is to interpret the meaning of the indung contained in the story of mythology carita pantun and ancient manuscripts. Leavy (2015) stated "The power of the image, and its role in society, cannot be underestimated. According to a popular expression, a picture is worth a thousand words".

\section{Method}

Art Based Research (ABR) is used as a method of creating indung in Sundanese mythological figures. ABR is a method of creating visual artworks based on the results of research, Leavy (2015) stated "ABR practices are a set of methodological tools used by qualitative researchers across the disciplines during all phases of social research, including data collection, analysis, interpretation, and representation". In relation to this, Leavy (2015) stated that "These emerging tools adapt the tenets of the creative arts in order to address social research questions in holistic and engaged ways in which theory and practice are intertwined."

Indung visual artwork in Sundanese mythological figures is the result of research conducted through art based research method, to interpret the results of the research using Visual Art techniques. Visual art techniques are now being used in methodological approaches to interpretation. The process of conducting research is always a meaning-making activity. Whether conducted within a paradigm based on "discovering" and "revealing" meaning, or one that posits the "creation" and the "construction" of meaning(s), social research is about generating meaning from data (Leavy 2015). According to the Encyclopedia of Art Education, definitions of visual arts include Fine Arts, Contemporary Arts, Decorative Arts \& Crafts, and Applied Art areas. Indung visual artwork in Sundanese mythology based on visual and technical concepts of materials used fall into one of the categories of definition of visual art namely Contemporary Arts. Data collection in research using literature, then analyzed and interpreted in the form of visual artwork.

\section{Result and Discussion}

\subsection{Sundanese Culture}

Sunda is the second largest ethnic group in Indonesia, with a total of 36.7 million people or about 15.5 percent (Raharja 2017). Sundanese name as a nation has a meaning. Sundanese meaning according to Djatikusumah ( Indrawardana 2014), divided into three basic concepts, first based on Sundanese philosophy means white, clean, luminous, great, beautiful and so on. Secondly based on ethnicity, Sundanese refer to the community, Sundanese are tribes created by God like other tribes in various nations on earth. Related to people who live with Sundanese culture and have characteristics as Sundanese. Thirdly based on geographical location, Sunda means referring to the map of the archipelago in the past which is divided into two areas namely Sunda Besar (great Sunda) which includes large islands in Indonesia such as Sumatra, Java, and Kalimantan, and Sunda Minor (Little Sunda) which includes small islands such as Bali, Lombok, Flores, Sumbawa, Roti, Nias, Belitung and others. 
According to Iskandar and Iskandar (2011), Sunda area in the past including the entire western part of Java Island, the eastern part is bounded Citanduy river and in the south by Cijulang River, north of Indramayu. In year of 2000, Sunda was administratively regulated by the Indonesian government covering West Java and Banten (Iskandar and Iskandar 2011). Suria Saputra (Sumardjo 2009), mentioned that Sundanese according to Baduy people must be qualified, namely, have Sundanese blood, speaking Sundanese, living in sunda areas, Sundanese civilized and sunda religion. According to Rosidi (1984), when viewed through the distribution in which Sundanese life and live, in general it can be said that everyday using Sundanese language and become supporters of Sundanese culture.

On literature about Sundanese people today, it can be grouped into two, namely indigenous groups such as Baduy, Cipta Gelar, Kampung Naga and Sundanese people outside the customary territory (West Java province and its surroundings). Baduy is a Sundanese who lives in Baduy area and who until now has maintained the original Sundanese culture as revealed by his ancestors (Iskandar and Iskandar 2011). Sundanese culture was created by Sundanese people, in this case Prawira (2017), stated; "There is no culture without a society, or no society without a culture, related to this social interaction of the community to bring the culture to life in the community". Sundanese culture today in accordance with the territory where they live, namely Baduy area, outside Baduy, and other indigenous areas such as Cipta Gelar and Kampung Naga have cultural differences. The traditional communities of Baduy, Cipta Gelar and Kampung Naga still run Sundanese culture, while Sundanese people in general who live in West Java and other areas (outside Baduy, Cipta Gelar and Kampung Naga), run syncretic cultures. Sundanese culture in general has the same cultural system as universal culture. Sundanese have language systems, knowledge, social organizations, technology, livelihoods, religion and the arts.

\subsection{Sundanese Beliefs}

West Java as the largest area where Sundanese live today, is the region with the highest Muslim population in Indonesia. According to the population census of the Central Statistics Agency (Badan Pusat Statistik) in 2010, the province with the most Muslim population is West Java with 41,763,592 people. Regarding to the beliefs of the Kingdoms of Cirebon and Banten, the majority of Sundanese converted to Islam. In addition to The Sundanese Islamic religion still believes in mystical things, superstition and $u g a$ (Forecast), making the nature of Sundanese syncretic (Rosidi 1984).

Sundanese belief system according to Ekadjati (1984), in prehistoric times adhered to the beliefs of animism and dynamism. Ancestral spirit worship through objects such as dolmen, menhir, undakan stone, carved stone, dakon stone, lumping stone and statue. In the time of Tarumanagara around the beginning of the 5th century to the 7 th century AD, the palace embraced Hindu Shiva and ordinary people worshipped the spirits of ancestors as a belief of the people since time immemorial. Syiwa Hinduism was adopted from the Sanjaya government in the Galuh Kingdom in the 7th century AD, until the time of The Sundanese King Sri Jayabhupati/Sang Rakeyan Darmasiksa, in Pakwan Pajajaran around the 10th century, worshipped Sanghiyang Tapak. During the reign of Wastu Kancana, around the 13th-14th century AD, practised Sanghyang Watangageung as a Sundanese Hindu belief. This belief was adopted until the end of the reign of Sri Baduga Maharaja or Prabu Siliwangi around the beginning of the 15th century AD (Ekadjati 1984).

\subsection{Indung in Sundanese Myth}

Sundanese traditional culture is the richness of Indonesian folklore. Like other cultures in the world, Sundanese have a wealth of folklore. Danandjaja (1986), defines folklore as part of the traditional culture of a collective spread and passed down through generations, either verbally, partly verbally or non-verbally. In general, folklore contains elements of mite, legend, ceremony, and song (Kusuma, n.d). Bascom (in Danandjaja 2007) states that folk prose stories can be divided into three major groups, namely myth, legend, and folktale.

Mythology is not a historical fact or an explicit cultural object, but an afterthought to study its meaning. Mythology as an afterthought indirectly describes the old Sundanese way of thinking that led to a mythical way of thinking, even considered irrational (Heryana 2012). With this mystical way of thinking, the old Sundanese people at that time had found and strengthened cultural values that remain valuable to Sundanese people now, even more likely to be needed. Related to this, culture according to Peursen (1980) consists of mitis, ontological, and functional. In mythic, man is ruled by the mythological mind realm, fascinated by the supernatural powers of nature, full of secrets, and responds to them in a "primitive" way. Ontologically, humans begin to question the nature of "something". Begin the human desire to distinguish one's self from the unseen. While functional, human beings use patterns or ways of thinking, by looking at things through practical and rational values (Heryana 2012).

Emeis (1971) suggests that mite is an ancient story from human times still feels united with the nature and supernatural events surrounding it. Mite usually depicts the birth of the nation, the meeting of the elders with Gods, spirits, and so on. William R. Bascom stated, is a story that is considered to be true as well as sacred by 
those who have stories. Mite is commanded by Gods or demigods, it happened in another world or in a world that is not the world we know it today, and the time has been a long time (Dananjaja 1986). Mite according to Hoykaas (in Heryana 2012) is the story of religiously sourced deities and is a belief of the origin of a nation or lineage, in addition to containing magic elements. According to Ridwan and Abdulgani (2012) myth, namely "Folk prose story that is tattooed by Gods or demigods who tell about the past and in a different world to the human world; usually myths tell about the origin of the universe, earth, plants, animals and so on. Myth is also believed by the owner of the story."

In Sundanese mythology there are Goddess figures, who live and some are still often the purpose of offering certain ceremonies in Sundanese society are Dayang Sumbi, Sunan Ambu, and Nyi Sri Pohaci (Heryana 2012). The characters are found in folklore that is spread orally, pantun stories, and ancient manuscripts. Dayang Sumbi figure is found in the legend of Sasangkala Gunung Tangkuban Parahu or Sangkuriang Kabeurangan. Sunan Ambu is found in carita pantun (pantun stories) such as, Tujuh Ronggeng Kalasirna, Demung Kalagan, Mundinglaya Dikusumah, Lutung Kasarung and Budak Manjor. Nyi Sri Pohaci is found in the ancient manuscript of Ksatriya Budug Basu (see figure 1) and in Ngalaksa ceremony of Rancakalong Sumedang people, and mythology of Kanekes Baduy Dalam people.

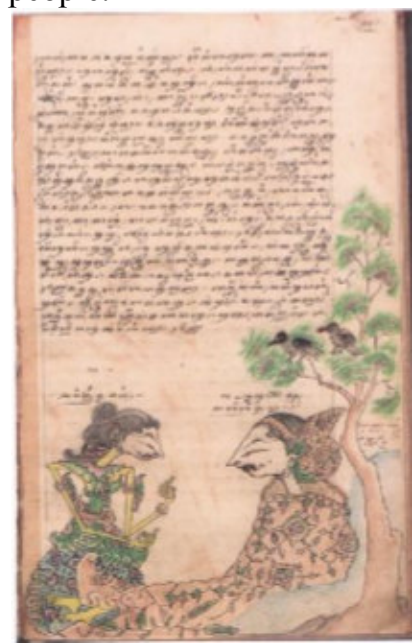

Figure 1. Illustration of Nyi Sri Pohaci (Dewi Sri) and Budug Basu in Ancient Manuscript Ksatriya Budug Basu.

Source : Ridwan and Abdulgani (2012). Penulisan Cerita Budug Basu di Kalangan Keraton

Cirebon. Jurnal Manasa Manuskripta. Vol. 2 No. 1

Related to the meaning of the indung, mythological figures in Sundanese culture are interpreted as a spirit of indung. Tohari (2013), stated in carita pantun Sri Sadana found that the nature of Sundanese human mind puts women in a great position and very honorable. Indung in the traditional perception of Sundanese people become the spiritual central figure of Sundanese. The indung becomes a symbol of perfection for the achievement of spirituality that is imagined in everyday life. Enoch Atmadibrata (Heryana 2006), stated The Glorification of indung by Sundanese people is depicted in indung figures contained in several mythological stories. In this case Anati's description of the earliest appearance of the Goddess is no less male-oriented. He writes, "These Upper Paleolithic men also created a feminine figure apparently representing a Goddess or being of fertility, the psychological implications of the mother Goddess are therefore of tremendous importance" (Stone 1976).

When looking at the statements of Tohari and Enoch Atmadibrata, indung that are attached to the physical form of Sundanese cultural artifacts and their meaning, is a cultural value or beliefs embraced (basic beliefs) of Sundanese society. Referring to anthropology, indung as cultural value is in the area of basic beliefs or Basic Assumptions. Trompenaars, F and Hampden-Turner explain it as follows;

"Down in the depths of onion, culture elements become increasingly more covered, secret, rarely noticed that invisible. on the outside of the onion lie explicit products of culture, as the observable reality of the language, food, buildings, houses, monuments, agriculture, shrines, markets, fashions and art" (Trompenaars dan Hampden-Turner 1958).

From the statement when looking at the concept of cultural elements Trompenaars, F and Hampden-Turner with the model of onion layer, indung is the basic assumptions of Sundanese society. The meaning of indung on Sundanese cultural artifacts as cultural elements that appear to remain not as explicit as the artifacts. The meaning of indung appears as a symbol that contains a deep meaning. 


\subsection{Visual Art of Indung in Sundanese Myth}

Indung artwork in Sundanese mythological figures is an artwork made based on research. Research was carried out on the existence of two indung figures namely Sunan Ambu contained in mythology or religious beliefs Kanekes Baduy Dalam and Dewi Sri or Nyi Sri Pohaci contained in the ancient manuscript Ksatriya Budug Basu. The work consists of two works, Indung of Aing and Nyi Sri Pohaci: Indung Pare. The concept is based on the results of research, namely data collection through literature.

3.4.1 Artwork : Indung of Aing

Indung of Aing concept is based on the results of literature, Saputra (Heryana, 2006) writes, in the belief of urang Kanekes, there is called Ambu Langit that is the woman who will assign Aing (human who is still in the womb) to descend into the world. By Ambu Langit, the Aing was handed over to Ambu Tengah named Nyi Randakasih. From Ambu tengah then descended again to Ambu Bumi named Ambu Dayang Wirati. Here Si Aing meets Ambu Dayang Wirati and receives love. So by the intercession of love and love of a mother and a father called Indung Simbarang Kandung (mother) and Bapa Simbarang Jadikeun (father), Si Aing human in the belly of Indung Simbarang Kandung. After nine months Si Aing spoke to Ambu for permission to travel in Buana Pancatengah (earth).

The literature is interpreted in visual artwork with depictions of Ambu Langit (mother of sky), Ambu Tengah (mother of middle) and Ambu Bumi (mother of earth) as bird and buterflies. Birds and buterfly are used as symbols of Goddesses. The indung are not depicted, the Aing as a human candidate is described as a fish that is in the womb of the Indung Simbarang Kandung (mother).

The visual style used batik tulis technique with batik pesisir motifs. Such as mega mendung, daun taleus, kumeli, and others. The use of color in this work follows the colors on batik pesisir, such as blue, purple, pink, yellow, orange and others that give a festive impression. Batik pesisir is a batik produced by batik craftman from the lower society. Decorative and color is richer because it gets influence from Chinese and Indo-Dutch culture, batik pesisir area that is the north coast of Java Island such as Indramayu, Cirebon, Tegal, Pekalongan, and others (Hasanudin 2001).

The work (as seen on figure 2) is made with batik tulis technique, using cold wax media from tamarine powder, this is a new batik technique that is popular in Indonesia today. Coloring using textile paint, fabric using polyester cloth with a size of $50 \times 150 \mathrm{~cm}$.

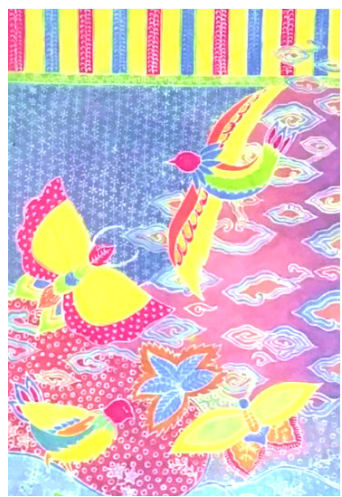

(a)

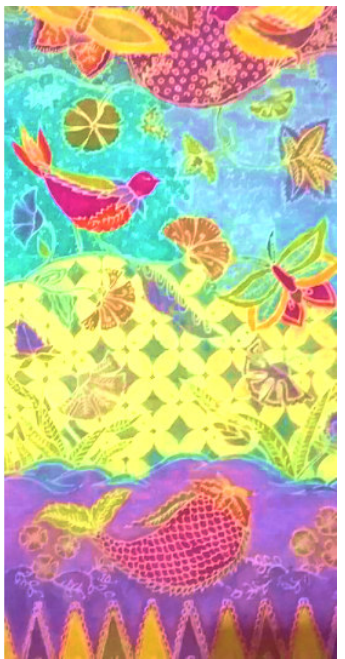

(b)

Figure 2. Indung of Aing, (a) The upper part of the artwork, (b) The bottom part of the artwork, measures $50 \times 150 \mathrm{~cm}$.

Source: https://www.artpal.com/rinimaulina and https://www.youtube.com/watch?v=CWtuHxj6v3w 3.4.2 Artwork: Nyi Sri Pohaci: Indung Pare

Nyi Sri Pohaci: Indung Pare concept is based on the results of literature, based on the ancient manuscript Serat Satriya Budug Basu written by Pangeran Sujatmaningrat (Ridwan and Abdulgani, 2012). In the ancient manuscript, there is a story about Budug Basu and Nyi Sri Pohaci (Dewi Sri). In Budug Basu's story, the characters are played by Gods, giants and humans (peasants). The setting of the story is mostly in Kahyangan, the world where the Gods live. The story contains of part of people's lives, namely agriculture, such as the origin of rice crops, irrigation, pests and others. In addition, there is a story as a public belief in the rice Goddess Dewi Sri as the origin of rice and Budug Basu as the origin of fish in the sea (Ridwan and Abdulgani 2012).

In the manuscript of serat Satriya Budug Basu, the origin of rice is come from the body of Nyi Sri Pohaci (Dewi Sri). According to Lombard, myths with such motives exist throughout the archipelago, including islands 
untouched by Indian influence (Sri's own name comes from India). The existence of the myth can not be separated from the cult of worship of Dewi Sri who is believed to be a fertility Goddess or rice Goddess for Javanese. This story is contained in many versions, found in Bali and Sulawesi. Lombard stated, the basic motive of this whole story is rice growing from the body or grave of a woman. So it can be said that the story of Budug Basu is one version of the rice myth story that developed in Cirebon, West Java (Ridwan and Abdulgani 2012).

The death of Nyi Sri Pohaci in serat Satriya Budug Basu, sacrificing her self for the earth. Nyi Sri Pohaci who is believed to be the embodiment of rice, respected by Sundanese people as well as her story in culture outside Sunda. Nyi Sri Pohaci in her death, from his body grew the appearance of plants, one of which was rice plants that grew from both eyes, and until now became a main food of Sundanese people.

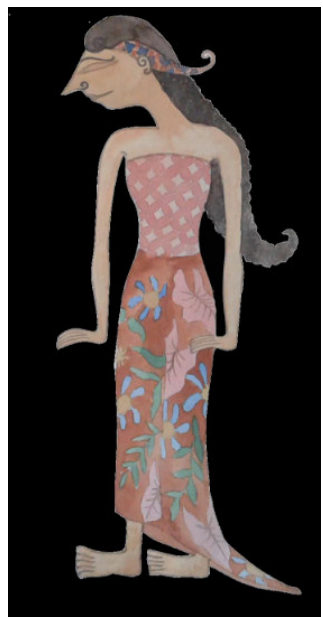

(a)

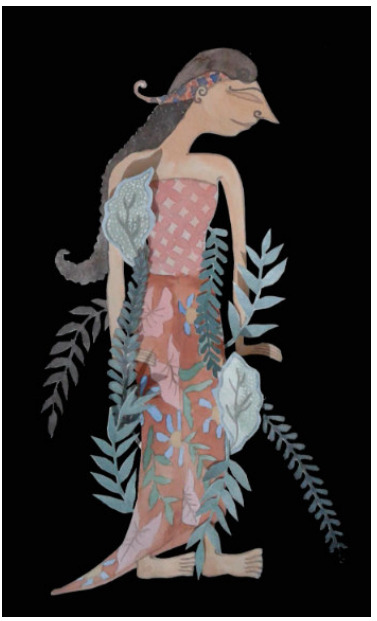

(b)

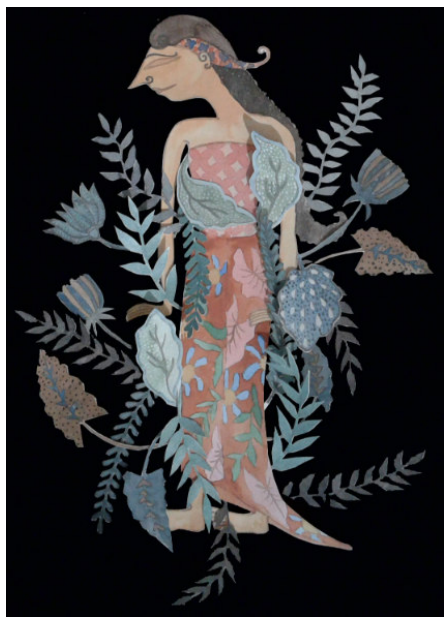

(c)

Figure 4. Nyi Sri Pohaci: Indung Pare, Three frames from 40 frames of stopmotion by Rini Maulina Source: http://fks.garasiseni10.com/nyi-sri-pohaci-indung-pare-by-rini-maulina/ https://youtu.be/PtkawC_JFaY

The literature is interpreted in the form of visual paper puppets with stop motion techniques (as seen on figure 4). The depiction of Nyi Sri Pohaci follows the visual style of a simplified leather puppet, equipped with various images of plants using paper media and water colors, the paper is cut into pieces and put together, then take for photos to produce 40 frames for making in the video produces stop motion work (artwork of stop motion available on https://youtu.be/PtkawC_JFaY) .

\section{Conclusion}

Indung of Aing's visual artwork is based on mythology found in the beliefs of the Kanekes community, Baduy Dalam. The mythological story is interpreted in the form of bird and buterflies visualization that symbolizes Goddesses such as Ambu Langit, Ambu Tengah and Ambu Bumi that deliver the Aing prospective human to Buana Panca Tengah (earth). Nyi Sri Pohaci: Indung Pare visual artwork is based on mythology found in the ancient manuscript of Satriya Budug Basu. The mythological story is presented in the form of paper puppet visualization with stop motion technique. To show the movement of plants growing out of her body.

Mythological figures Ambu Langit, Ambu Tengah, Ambu Bumi, and Nyi Sri Pohaci are characters who have the spirit of indung, as stated by Heryana, indung is aimed not only at humans but can be directed towards something, such as objects or other, taken from indung is the nature of motherhood, the characteristics of indung contained in women, as well as Mustafa gives an meaning of the indung that is who educates children from childhood, even if it is not human, it should be called indung. Related to the meaning of the indung, mythological figures Ambu Langit, Ambu Tengah and Ambu Bumi are Goddesses who have the spirit of indung and the nature of motherhood that is accompanying Si Aing as a human candidate to survive to the stomach of the Indung Simbarang Kandung (biological mother).

Similarly, the figure of Nyi Sri Pohaci as a rice Goddess is believed by Sundanese as a Goddess who gives life, has a female nature and has a spirit of indung that nurtures and gives life to living things, especially humans. Mythological figures in Sunda are portrayed as female characters, as well as the depiction of mythological figures in the world, it is as stated by Stone that paleolithic people create a feminine figure representing the Goddess of fertility, as the psychological implications of the mother Goddess, as a very important thing. The creation of visual artwork based on Sundanese literature on Sunan Ambu (in this case Ambu Langit, Ambu Tengah and Ambu Bumi) and Dewi Sri in the Sundanese version in this case Nyi Sri Pohaci, is the creation of visual artwork interpreting the meaning of the indung contained in the story of Sundanese mythology, the use of 
visual styles taken from the traditional visual style of batik and wayang (puppets) to be recognized as visual artworks that elevate the nature of the indung contained in Sundanese mythological figures with the visual style of traditional art.

\section{References}

Danandjaya, James. (1986). Folklor Indonesia. (2nd ed). Jakarta: Pustaka Grafitpers,

Ekadjati, Edi S. (1984). Masyarakat Sunda dan Kebudayaannya. Girimukti: Pasaka

Emeis, M.G. (1971). Bunga Rampai Melayu Kuno. Kualalumpur Malaysia: Dewan Bahasa dan Pustaka.

Hasanudin. (2001). Batik Pesisiran: Melacak pengaruh Etos Dagang Santri pada Ragam Hias Batik. Bandung. Kiblat.

Heryana, Agus. (2006). Indung, Konsep dan Aktualitas Perempuan Sunda. Bandung :Balai Pelestarian Nilai Budaya.

Heryana, Agus. (2012). Mitologi Perempuan Sunda. Patanjala Journal, 4 (1), 156-169.

Indrawardana, Ira. (2014). Berketuhanan dalam perspektif Kepercayaan Sunda Wiwitan. Melintas Journal, 30 (1), 105-118.

Iskandar, Johan., Budiawati, S Iskandar. (2011). Agroekosistem Orang Sunda. Bandung: Kiblat.

Kak, Subhash. (2020). The Great Goddess Lalita And The Sri Chakra. Retrieved, [Online] Available: https://swarajyamag.com/culture/the-great-goddess-lalita-and-the-sri-chakra (October, 15, 2020)

Kusuma, Dewi. (2019). Mite "Nyi Pohaci Sanghyang Asri” Sebagai Refleksi Kearifan Lingkungan. Cirebon: Universitas Nahdatul Ulama Cirebon.

Koentjaraningrat. (2009). Pengantar Ilmu Antropologi. Jakarta : Rineka Cipta.

Leavy, Patricia. (2015). Method Meets Art, Art Based Research Practice. New York, London: The Guilford Press (Cahpter 7).

Leeming, David A. (2010). Creation Myths of The World. California, Colorado England : Greenwood Publishing Group.

Maulina, Rini. (2019). Indung Pada Waditra Kacapi. Visualita Journal, 7 (2), 45-59

Mustapa, R.H. Hasan. (1985). Adat Istiadat Orang Sunda. Bandung: Penerbit Alumni.

Na'im, Akhsan. Syaputra, Hendry. (2010). Kewarganegaraan, Suku Bangsa, Agama, dan Bahasa Sehari-hari Penduduk Indonesia. Jakarta: Badan Pusat Statistik.

Peursen, Van. (1980). Orientasi di Alam Filsafat. Jakarta: Gramedia.

Prawira, Nanang Ganda. (2017). Pamandangan Reka Hias Baduy: Fungsi, Bentuk, Motif, Simbol, di Desa Kanekes, Kecamatan Leuwidamar, Kabupaten Lebak, Jawa Barat. Bandung: Bintang warli Artika.

Raharja, Mugia Bayu. (2017). Fertility by Ethnicity in Indonesia: Analysis of 2010 Indonesian Population Census. Kependudukan Indonesia Journal, 12 (1), 69-78

Ridwan, Sinta and Abdulgani, Fuad. 2012. Penulisan Cerita Budug Basu di Kalangan Keraton Cirebon. Manasa Manuskripta Journal, 2 (1 ), 119-138.

Rosidi, Ajip. (1984). Manusia Sunda. Jakarta: Inti Idayu Press.

Stone, Merlin. 1976. When God Was a Woman. Great Britain: Quartet Books Limited.

Sumardjo, Jakob. 2009. Kosmologi dan Pola Tiga Sunda. Imaji Journal, 4 (2), 101-110

Tohari, Heri Mohamad. 2013. Feminisme Sunda Kuno: Studi Interpretasi Kritis Akulturasi Nilai-nilai Kesetaraan Gender Sunda-Islam Dalam Carita Pantun Sri Sadana. Etika dan Pekerti Journal, 1 (2), 13-26.

Trompenaars, Fons and Hampden-Turner, Charles. 1997. Riding The Waves of Culture: Understansing Diversity in Global Business. London : Nicholas Brealey.

World Book-Childcraft International, inc. (1987). Childcraft: The How and Why Library. About Us. Vol 8. Chicago, USA: World Book-Childcraft International, inc.

Yanti, Neneng. 2006. Sosok Ibu dan Spiritualitas. Pikiran Rakyat, Desember 222006. 